ORIGINAL ARTICLE

\title{
Diversity patterns of hawkmoths (Lepidoptera: Sphingidae) in the canopy of an ombrophilous forest in Central Amazon, Brazil
}

\author{
Gilcélia Melo LOURIDO ${ }^{1 *}$, Catarina da Silva MOTTA ${ }^{\dagger}$, Márlon Breno GRAÇA ${ }^{1}$, José Albertino RAFAEL ${ }^{1}$ \\ Instituto Nacional de Pesquisas da Amazônia (INPA), Coordenação de Biodiversidade (COBIO), Manaus, Amazonas, Brasil \\ In memoriam \\ * Corresponding author: lourido@inpa.gov.br
}

\begin{abstract}
Sphingidae attracted to light were systematically collected in an Amazonian forest canopy. Sampling occurred at a height of $34 \mathrm{~m}$ in an upland primary rainforest plateau in the Cueiras river basin, located within the Experimental Station of Tropical Silviculture, Manaus municipality, Amazonas, Brazil. The hawkmoths were collected using a vertical white sheet illuminated by a $250 \mathrm{~W}$ mixed mercury light and a $20 \mathrm{~W}$ black-light (BLB) fluorescent tube. Monthly collections were carried out from January to December 2004, during three nights of lunar transition from third quarter moon to new moon between 6 p.m. and 6 a.m. We sampled 1748 specimens, represented by 1485 males and 263 females, belonging to 52 species and 21 genera. Xylophanes comprised the highest number of species (seven), followed by Erinnyis, with six species. The most abundant species were Pseudosphinx tetrio (169 specimens), Pachylia darceta (162), Erinnyis ello ello (154), Isognathus excelsior (151) and Callionima parce (139). The species accumulation curve showed that the species richness tended to stabilize by the eighth month. We also observed that species composition altered significantly throughout the night period. All presented hawkmoth records are new for the canopy in the Central Amazon.
\end{abstract}

KEYWORDS: Amazon rainforest, flight activity, forest canopy, species composition, species richness

\section{Padrões de diversidade de Sphingidae (Lepidoptera) no dossel de floresta ombrófila na Amazônia Central, Brasil}

\section{RESUMO}

Foram realizadas coletas sistemáticas de Sphingidae no dossel de floresta ombrófila densa na Amazônia Central utilizandose armadilha luminosa. As coletas ocorreram em uma floresta primária de terra firme, na bacia do Rio Cuieiras, a $34 \mathrm{~m}$ de altura na torre da Estação Experimental de Silvicultura Tropical, Manaus, Amazonas, Brasil. Foi utilizado um lençol branco iluminado com uma lâmpada de luz mista de mercúrio e uma lâmpada de luz negra UV-BLB. As mariposas foram coletadas mensalmente durante o ano de 2004, em três noites consecutivas de lua minguante e/ou lua nova, sempre das 18:00 às 06:00h. Foram coletados 1748 espécimes, dos quais 769, por serem comuns, foram identificados, marcados e soltos. Foram obtidos 1485 machos e 263 fêmeas, pertencentes a 21 gêneros e 52 espécies. Xylophanes foi representado por sete espécies, seguido por Erinnyis com seis. As espécies mais abundantes foram Pseudosphinx tetrio (169 espécimes), Pachylia darceta (162), Erinnyis ello ello (154), Isognathus excelsior (151) e Callionima parce (139). A curva de acumulação de espécie mostrou que em torno do oitavo mês de coleta, a riqueza de espécies tende a estabilizar. Foi possível observar ainda que a composição de esfingídeos mudou significativamente ao longo da noite. Todos os registros são novos para o dossel de floresta na Amazônia Central.

PALAVRAS-CHAVE: atividade de voo, composição de espécies, dossel, floresta amazônica, riqueza de espécies 


\section{INTRODUCTION}

The family Sphingidae comprises predominantly nocturnal moths, which execute important ecological functions in the insect-plant interactions, either by herbivory (caterpillars) or pollination (adults) (Motta 1993). Due to the high amount of leaves that the juveniles can consume, some species are able to heavily injure their hosts. However, in their natural habitat, they rarely threaten the populations of host plants (Kitching and Cadiou 2000).

Sphingidae includes around 200 genera and 1270 species worldwide (Kitching and Cadiou 2000), with 400 species in the Neotropical region (Carcasson and Heppner 1996). In Brazil, there are records of 197 species (Duarte et al. 2017) and 128 are reported from the Brazilian Amazon (Camargo et al. 2016a).

The flight activity of hawkmoths is rather well documented, but most studies have tackled species flying at the understorey level (e.g., Motta et al. 1998). Canopy sampling of these moths is lacking, which results in a gap on knowledge regarding their diversity, life history and behaviour in upper forest layers, especially in the Amazon. This lack of studies is mainly due to methodological and logistic obstacles to access the canopy.

In the Amazon rainforest, nocturnal sampling in towers to reach the canopy has enabled the survey and the discovery of new species in other insect groups, including Cerambycidae (Coleoptera) (Martins et al. 2006), Mantispidae (Neuroptera) (Machado 2007; Machado and Rafael 2007), praying mantises (Mantodea) (Dantas et al. 2008), Hedylidae (Lepidoptera) (Lourido et al. 2008) and Tabanidae (Diptera) (Krolow et al. 2010). These studies have shown that many species rarely sampled in lower forest strata are actually quite abundant in the canopy and many others that occur predominantly in the canopy. Hence, our study aimed at surveying hawkmoths attracted to light at canopy level in an Amazonian ombrophilous forest, and to describe diversity patterns (richness, abundance, frequency and species composition) along temporal scales.

\section{MATERIAL AND METHODS}

\section{Study site}

The hawkmoths were collected in a $40 \mathrm{~m}$ tower located in the KM 14 (ZF-2 nucleus, 2035'21"S, 60\%06'55”W) of the Tropical Silviculture Experimental Station, Manaus, Amazonas, Brazil. The station is under the administration of the National Institute for Amazonian Research (INPA).

According to the Köppen climate classification, the climate of the station is of the Am type, with low annual thermic range and average monthly rainfall over $60 \mathrm{~mm}$. The annual average temperature is $26.7^{\circ} \mathrm{C}$, ranging between $23.3^{\circ} \mathrm{C}$ and $31.4^{\circ} \mathrm{C}$, while annual average rainfall is $2286 \mathrm{~mm}$ and relative humidity is around $80 \%$; the rainy season goes from December to May, and the dry season goes from June to November (Barbosa 2015).
The tower used for samplings is metallic and $40 \mathrm{~m}$ high and is located inside a typical Amazonian landscape, which comprises an ombrophilous dense forest with a canopy reaching up to $40 \mathrm{~m}$, sometimes $50 \mathrm{~m}$ due to emergent trees. In this sort of forest, it is rather difficult to distinguish between median and lower strata, but the mean canopy height in the Amazon is $28.6 \mathrm{~m}$ (Higuchi et al. 2009). A description of the flora of the station can be found in Martins et al. (2006).

\section{Hawkmoth sampling}

We carried out monthly nocturnal samplings from January to December 2004, at a height of $34 \mathrm{~m}$. In each month, we surveyed hawkmoths during three nights of lunar transition from third quarter moon to new moon between 6 p.m. and 6 a.m. To attract the moths, we lighted a mercury lamp and an ultraviolet bulb (UV-BLB) next to a $1.40 \times 2.20$ m white sheet. We captured the moths that landed on the sheet with insect nets or by direct handling. Most specimens were killed and kept in paper envelops for subsequent identification. Common species were identified in the field, marked and released. We followed D'Abrera (1986) and Kitching and Cadiou (2000) for identifications. The classification of the species was based on the latter authors. The material sampled is housed at the Invertebrate Collection of INPA.

\section{Statistical analyses}

We developed a species accumulation curve to verify the sampling sufficiency of species richness across twelve months in statistical software EstimateS version 9.1 (Colwell, 2013). We performed 1000 randomizations, extrapolating to the total number of samples (12) and using the Chao1 and Chao2 bias correction. Finally, we used Nonmetric Multidimensional Scaling (NMDS, Minchin 1987) to ordinate the hourly intervals of sampling according to their species composition, to verify whether species displayed a preference for a particular flying period. The latter analysis was conducted in $\mathrm{R}$ version 3.3.3. (R Core Team 2017) using package vegan 2.4-0 (Oksanen et al. 2016)

\section{RESULTS}

We collected 1748 specimens belonging to 52 species, 21 genera, six tribes and three subfamilies (Table 1). Overall, we marked and released 769 specimens. Macroglossinae had the highest abundance (1317 specimens, 75\%), followed by Smerinthinae (295 specimens, 17\%) and Sphinginae (136 specimens, 8\%). Similarly, Macroglossinae comprised the highest richness, with 38 species (73\%). Xylophanes Hübner, Erinnyis Hübner and Eumorpha Hübner were the most species-rich genera, with seven, six and five species respectively. The majority of the genera (62\%) were represented by more than one species. The most abundant genus was Erinnyis, with 322 specimens, followed by Callionima Lucas (243 specimens) and Protambulyx Rothschild \& Jordan (191 specimens) (Table 1). The most frequent species were Adhemarius palmeri (Boisduval), Callionima parce (Fabricius), 
Table 1. Richness and abundance of species of hawkmoths during 12 months of sampling on the ZF-2 tower, Tropical Silviculture Experimental Station, Manaus, Amazonas, Brazil. $N$ = number of individuals.

\begin{tabular}{|c|c|c|c|c|c|c|}
\hline Subfamily & Tribe & Species & $\begin{array}{c}\mathrm{N} \\
\text { males }\end{array}$ & $\begin{array}{c}\mathrm{N} \\
\text { females }\end{array}$ & $\begin{array}{c}\mathrm{N} \\
\text { specimens }\end{array}$ & $\begin{array}{c}\text { Relative } \\
\text { abundance (\%) }\end{array}$ \\
\hline \multirow[t]{6}{*}{ Smerinthinae } & & & & & 295 & 16.88 \\
\hline & \multirow{5}{*}{ Ambulycini } & Adhemarius gannascus gannascus (Stoll, 1790) & 22 & & 22 & 1.26 \\
\hline & & Adhemarius palmeri (Boisduval, [1875]) & 76 & 6 & 82 & 4.69 \\
\hline & & Protambulyx eurycles (Herrich-Schäffer, [1854]) & 46 & 2 & 48 & 2.75 \\
\hline & & Protambulyx goeldii Rothschild \& Jordan, 1903 & 78 & 2 & 80 & 4.58 \\
\hline & & Protambulyx strigilis (Linnaeus, 1771) & 57 & 6 & 63 & 3.6 \\
\hline \multirow[t]{10}{*}{ Sphinginae } & & & & & 136 & 7.78 \\
\hline & \multirow{8}{*}{ Sphingini } & Amphimoea walkeri (Boisduval, [1875]) & 4 & & 4 & 0.23 \\
\hline & & Cocytius duponchel (Poey, 1832) & 74 & 19 & 93 & 5.32 \\
\hline & & Cocytius /ucifer Rothschild \& Jordan, 1903 & 3 & & 3 & 0.17 \\
\hline & & Manduca brunalba (Clark, 1929) & 6 & 1 & 7 & 0.4 \\
\hline & & Manduca dalica dalica (Kirby, 1877) & 6 & 1 & 7 & 0.4 \\
\hline & & Manduca leucospila (Rothschild \& Jordan, 1903) & 2 & & 2 & 0.11 \\
\hline & & Manduca lucetius (Cramer, 1780) & 10 & & 10 & 0.57 \\
\hline & & Neococytius cluentius (Cramer, 1775) & 2 & 4 & 6 & 0.34 \\
\hline & Acheronthiini & Agrius cingulata (Fabricius, 1775) & 3 & 1 & 4 & 0.23 \\
\hline \multirow[t]{32}{*}{ Macroglossinae } & & & & & 1317 & 75.34 \\
\hline & \multirow{26}{*}{ Dilophonotini } & Aellopos fadus (Cramer, 1775) & 2 & 1 & 3 & 0.17 \\
\hline & & Callionima inuus (Rothschild \& Jordan, 1903) & 15 & 1 & 16 & 0.92 \\
\hline & & Callionima nomius (Walker, 1856) & 37 & 1 & 38 & 2.17 \\
\hline & & Callionima pan pan (Cramer, 1779) & 50 & & 50 & 2.86 \\
\hline & & Callionima parce (Fabricius, 1775) & 133 & 6 & 139 & 7.95 \\
\hline & & Enyo lugubris lugubris (Linnaeus, 1771) & 17 & 4 & 21 & 1.2 \\
\hline & & Enyo ocypete (Linnaeus, 1758) & 14 & 2 & 16 & 0.92 \\
\hline & & Erinnyis alope alope (Drury, 1773) & 39 & & 39 & 2.23 \\
\hline & & Erinnyis crameri (Schaus, 1898) & 2 & & 2 & 0.11 \\
\hline & & Erinnyis domingonis (Butler, 1875) & 1 & & 1 & 0.06 \\
\hline & & Erinnyis ello ello (Linnaeus, 1758) & 90 & 64 & 154 & 8.81 \\
\hline & & Erinnyis obscura obscura (Fabricius, 1775) & 42 & 24 & 66 & 3.78 \\
\hline & & Erinnyis oenotrus (Cramer, 1780) & 47 & 13 & 60 & 3.43 \\
\hline & & Eupyrrhoglossum venustum Rothschild \& Jordan, 1910 & 16 & & 16 & 0.92 \\
\hline & & Hemeroplanes ornatus Rothschild, 1894 & & 1 & 1 & 0.06 \\
\hline & & Isognathus excelsior (Boisduval, [1875]) & 149 & 2 & 151 & 8.64 \\
\hline & & Isognathus leachii (Swainson,1823) & 20 & & 20 & 1.14 \\
\hline & & Isognathus occidentalis Clark, 1929 & 3 & & 3 & 0.17 \\
\hline & & Madoryx bubastus bubastus (Cramer, 1777) & 1 & & 1 & 0.06 \\
\hline & & Madoryx plutonius (Hübner, [1819]) & 11 & & 11 & 0.63 \\
\hline & & Pachylia darceta Druce, 1881 & 158 & 4 & 162 & 9.27 \\
\hline & & Pachylia ficus (Linnaeus, 1758) & 18 & 7 & 25 & 1.43 \\
\hline & & Perigonia lusca lusca (Fabricius, 1777) & 1 & 2 & 3 & 0.17 \\
\hline & & Perigonia pallida Rothschild \& Jordan, 1903 & 3 & & 3 & 0.17 \\
\hline & & Pseudosphinx tetrio (Linnaeus, 1771) & 100 & 69 & 169 & 9.67 \\
\hline & & Unzela pronoe pronoe Druce, 1894 & 1 & & 1 & 0.06 \\
\hline & \multirow{5}{*}{ Philampelini } & Eumorpha anchemolus (Cramer, 1779) & 19 & 11 & 30 & 1.72 \\
\hline & & Eumorpha capronnieri (Boisduval, [1875]) & 1 & 1 & 2 & 0.11 \\
\hline & & Eumorpha fasciatus (Sulzer, 1776) & 1 & & 1 & 0.06 \\
\hline & & Eumorpha obliquus obliquus (Rothschild \& Jordan, 1903) & 6 & & 6 & 0.34 \\
\hline & & Eumorpha phorbas (Cramer, 1775) & 9 & & 9 & 0.51 \\
\hline
\end{tabular}


Table 1. Continued

\begin{tabular}{|c|c|c|c|c|c|c|}
\hline Subfamily & Tribe & Species & $\begin{array}{c}\mathrm{N} \\
\text { males }\end{array}$ & $\begin{array}{c}N \\
\text { females }\end{array}$ & $\begin{array}{c}N \\
\text { specimens }\end{array}$ & $\begin{array}{c}\text { Relative } \\
\text { abundance (\%) }\end{array}$ \\
\hline & \multirow{7}{*}{ Macroglossini } & Xylophanes amadis (Stoll, 1782) & 2 & & 2 & 0.11 \\
\hline & & Xylophanes chiron nechus (Cramer, 1777) & 52 & 7 & 59 & 3.37 \\
\hline & & Xylophanes guianensis (Rothschild, 1894) & 1 & & 1 & 0.06 \\
\hline & & Xylophanes haxairei Cadiou, 1985 & 1 & & 1 & 0.06 \\
\hline & & Xylophanes schausi schausi (Rothschild, 1894) & 1 & & 1 & 0.06 \\
\hline & & Xylophanes tersa tersa (Linnaeus, 1771) & 7 & 1 & 8 & 0.46 \\
\hline & & Xylophanes thyelia thyelia (Linnaeus, 1758) & 26 & & 26 & 1.49 \\
\hline TOTAL & & & 1485 & 263 & 1748 & 100 \\
\hline
\end{tabular}

Cocytius duponchel (Poey), Isognathus excelsior (Boisduval), Protambulyx goeldii (Rothschild \& Jordan), Protambulyx strigilis (Linnaeus) and Xylophanes thyelia (Linnaeus), which were sampled in all 12 months (Table 2).

The five most abundant species were Pseudosphinx tetrio (Linnaeus), Pachylia darceta Druce, Erinnyis ello ello (Linnaeus), Isognathus excelsior and Callionima parce (Table 2). With 169 specimens, Pseudosphinx tetrio peaked in September (85 specimens) and was collected during all year, except in April. Pachylia darceta had two abundance peaks, in September (26 specimens) and December (27 specimens), and was not sampled in June. Similarly, Erinnyis ello ello peaked in both March and April with 89 specimens overall. Isognathus excelsior occurred throughout the year, with the highest abundance in October and December (52 specimens overall). Callionima parce also occurred in all sampled months and, from the 139 specimens, 63\% were registered from September to December. Thirty species $(-58 \%)$ had relative abundance lower than $1 \%$.

Overall, we collected 1485 males and 263 females. For 23 species, we only sampled males. The few species with a higher proportion of females, Neococytius cluentius (Cramer) and Perigonia lusca (Fabricius), had rather low populations (six and three specimens, respectively). Hemeroplanes ornatus Rothschild was the only singleton represented by a female.

The species accumulation curve did not stabilize (Figure 1 ), as expected. However, by the eighth month, few species were added to the sample. Species richness did not vary considerably between hourly intervals (Figure 2), but we observed a turnover in species composition across the night (Figure 3). By analyzing our results, we could perceive a differentiation in species composition among four main periods: dusk (6 to 7 p.m.), night before midnight (7 p.m. to midnight), night after midnight (midnight to $4 \mathrm{a} . \mathrm{m}$.) and dawn (4 to 6 a.m.) (Figure 3). As for the abundance, the peak of flying activity was observed between midnight and 2 a.m., when we sampled $26 \%$ of all hawkmoth specimens. In contrast, dusk (6 to 7 p.m.) represented the period with the lowest hawkmoth abundance.

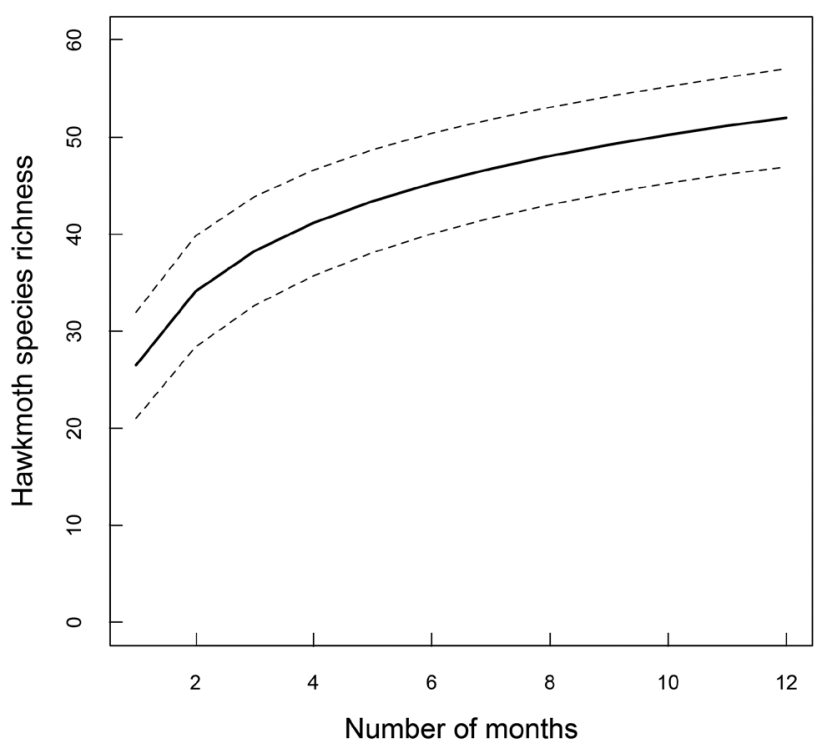

Figure 1. Accumulation curve of species richness of hawkmoths throughout 12 months of sampling on the ZF-2 tower, Tropical Silviculture Experimental Station, Manaus, Amazonas, Brazil. Dashed lines are the 95\% C.I.

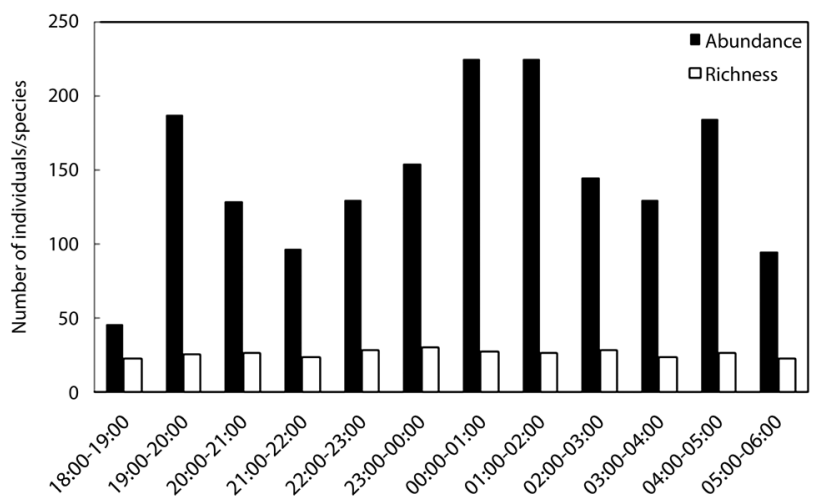

Figure 2. Abundance and richness of hawkmoths by hourly intervals across the night across 12 months on the sampling on the ZF-2 tower, Tropical Silviculture Experimental Station, Manaus, Amazonas, Brazil. 
Table 2. Number of individual hawkmoths per month during one year of sampling on the ZF-2 tower, Tropical Silviculture Experimental Station, Manaus, Amazonas, Brazil.

\begin{tabular}{|c|c|c|c|c|c|c|c|c|c|c|c|c|}
\hline Genus/Species/Subspecies & Jan & Feb & Mar & Apr & May & Jun & Jul & Aug & Sep & Oct & Nov & Dec \\
\hline Adhemarius g. gannascus & & & 2 & 1 & & & & 2 & 5 & 6 & 1 & 5 \\
\hline Adhemarius palmeri & 1 & 7 & 16 & 4 & 3 & 5 & 2 & 10 & 3 & 5 & 11 & 15 \\
\hline Aellopos fadus & & & & & & & & & & & & 3 \\
\hline Agrius cingulata & 2 & & & 1 & & & & & 1 & & & \\
\hline Amphimoea walkeri & & & 1 & & & & 1 & & 1 & & 1 & \\
\hline Callionima inuus & & & & & & & & 1 & 3 & 7 & 3 & 2 \\
\hline Callionima nomius & 1 & 5 & 4 & & 1 & 2 & 2 & 8 & 2 & 3 & 5 & 5 \\
\hline Callionima p.pan & & 8 & 3 & 9 & 7 & 2 & 4 & 3 & 7 & 2 & 2 & 3 \\
\hline Callionima parce & 9 & 16 & 5 & 4 & 5 & 5 & 5 & 2 & 20 & 18 & 29 & 21 \\
\hline Cocytius duponchel & 7 & 4 & 4 & 8 & 5 & 2 & 17 & 15 & 9 & 9 & 4 & 9 \\
\hline Cocytius lucifer & & & & & & 1 & & & & 2 & & \\
\hline Enyol. lugubris & & & & & & & 2 & 1 & 1 & 1 & 1 & 15 \\
\hline Enyo ocypete & 1 & 1 & 1 & & 1 & 1 & 7 & & & 3 & & 1 \\
\hline Erinnyis a. alope & 1 & 3 & 9 & & 3 & 7 & 9 & & 2 & & 2 & 3 \\
\hline Erinnyis crameri & & & & & & & 1 & & 1 & & & \\
\hline Erinnyis domingonis & & & & & & & & & & & & 1 \\
\hline Erinnyis e. ello & 7 & 5 & 54 & 35 & 1 & & 6 & 12 & 8 & 11 & 12 & 3 \\
\hline Erinnyis o. obscura & & & 1 & & & & & & & 1 & 9 & 55 \\
\hline Erinnyis oenotrus & 3 & 2 & 15 & 8 & 3 & 1 & 7 & 3 & 3 & & & 15 \\
\hline Eumorpha anchemolus & 3 & 1 & 3 & 1 & & 7 & 5 & & 5 & 3 & & 2 \\
\hline Eumorpha capronnieri & 1 & & & & & & & 1 & & & & \\
\hline Eumorpha fasciatus & & & & & & & 1 & & & & & \\
\hline Eumorpha o. obliquus & & & & 1 & & 1 & 2 & 2 & & & & \\
\hline Eumorphaphorbas & 1 & 3 & & 1 & 1 & & & & 2 & & & 1 \\
\hline Eupyrrhoglossum venustum & 1 & 1 & 1 & 1 & & & 3 & 2 & 1 & & 1 & 5 \\
\hline Hemeroplanes ornatus & & & & & & & & & & & & 1 \\
\hline Isognathus excelsior & 13 & 11 & 8 & 5 & 5 & 9 & 12 & 17 & 10 & 21 & 9 & 31 \\
\hline Isognathus leachii & 3 & & 2 & 1 & & 1 & 1 & & 3 & & 5 & 4 \\
\hline Isognathus occidentalis & & & & 1 & 1 & & & & & & 1 & \\
\hline Madoryx b. bubastus & & & & & & & & & & & 1 & \\
\hline Madoryx plutonius & 2 & 2 & 1 & & 1 & 1 & & 1 & 1 & 1 & 1 & \\
\hline Manduca brunalba & & & & & & 1 & 1 & 1 & 3 & 1 & & \\
\hline Manduca d. dalica & & & & & & 1 & 1 & 3 & 1 & 1 & & \\
\hline Manduca leucospila & & & & & & & & & 2 & & & \\
\hline Manduca lucetius & & 2 & 1 & & & 3 & & 1 & & 1 & 1 & 1 \\
\hline Neococytius cluentius & 1 & & 4 & & & & & 1 & & & & \\
\hline Pachylia darceta & 3 & 14 & 20 & 12 & 8 & & 13 & 12 & 26 & 12 & 15 & 27 \\
\hline Pachylia ficus & & 2 & 2 & 2 & 1 & 1 & & & 6 & 4 & 2 & 5 \\
\hline Perigonia I. lusca & & & & & & & 1 & & & & & 2 \\
\hline Perigonia pallida & & & & & & & 2 & & 1 & & & \\
\hline Protambulyx eurycles & & 5 & 3 & 4 & 3 & 1 & 3 & 5 & 2 & 4 & 10 & 8 \\
\hline Protambulyx goeldii & 1 & 7 & 3 & 4 & 1 & 3 & 3 & 3 & 9 & 6 & 12 & 28 \\
\hline Protambulyx strigilis & 3 & 5 & 7 & 8 & 2 & 1 & 8 & 3 & 9 & 4 & 5 & 8 \\
\hline Pseudosphinx tetrio & 1 & 2 & 5 & & & 1 & 14 & 4 & 85 & 14 & 35 & 8 \\
\hline Unzela p.pronoe & & & & & & & & & & & 1 & \\
\hline Xylophanes amadis & & & & & 1 & & 1 & & & & & \\
\hline Xylophanes chiron nechus & 2 & 1 & 6 & 4 & & 1 & 9 & 6 & 12 & & 3 & 15 \\
\hline Xylophanes guianensis & & 1 & & & & & & & & & & \\
\hline Xylophanes haxairei & & 1 & & & & & & & & & & \\
\hline Xylophanes s. schausi & & & & & & & & & & 1 & & \\
\hline Xylophanes t. tersa & 2 & & 4 & & & & & & & & 1 & 1 \\
\hline Xylophanes t. thyelia & 2 & 1 & 3 & 4 & 1 & 1 & 2 & 3 & 4 & 1 & 2 & 2 \\
\hline
\end{tabular}




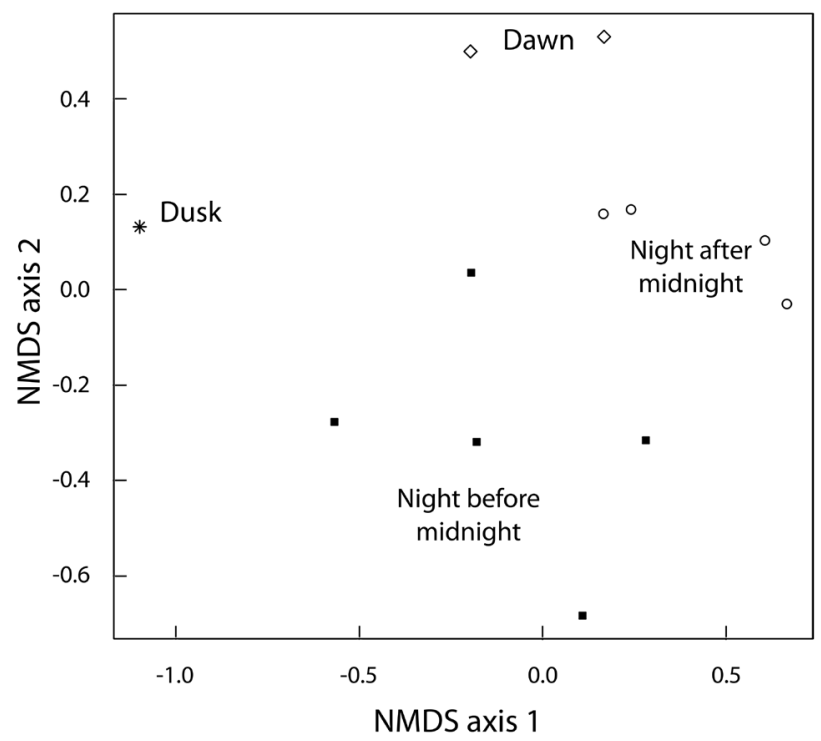

Figure 3. First two NMDS ordination axes considering hawkmoth species composition as a function of time of sampling.
Pseudosphinx tetrio, the most abundant species, had a constant flight activity, with more abundance for the time interval of 1:00 to 2:00 a.m., when 27 specimens were recorded, corresponding to approximately $12 \%$ of the individuals collected during this time interval (Figure 4). Pachylia darceta was more abundant for the interval of 10:00 to 11:00 p.m., with a record of 44 specimens, which declined after that time. Erinnyis ello ello presented the highest number of individuals in the 4:00 to 5:00 a.m. interval (Figure 4). The highest numbers of females were also captured during this interval, with Erinnyis ello ello predominating with 19 females. This figure corresponds to $42 \%$ of the total number of females collected during this interval. The peak flight activity for Isognathus excelsior was during the interval of 00:00 to 2:00 a.m., when 91 specimens were recorded, which is about $60 \%$ of the total captured for this species (Figure 4). Callionima parce had its peak flight activity during the interval of 7:00 to 8:00 p.m. (Figure 4), with 59 specimens, which is about $36 \%$ of the total captured, and the activity started decreasing from this interval. This pattern suggests that the more abundant species tend to fly at different time intervals.

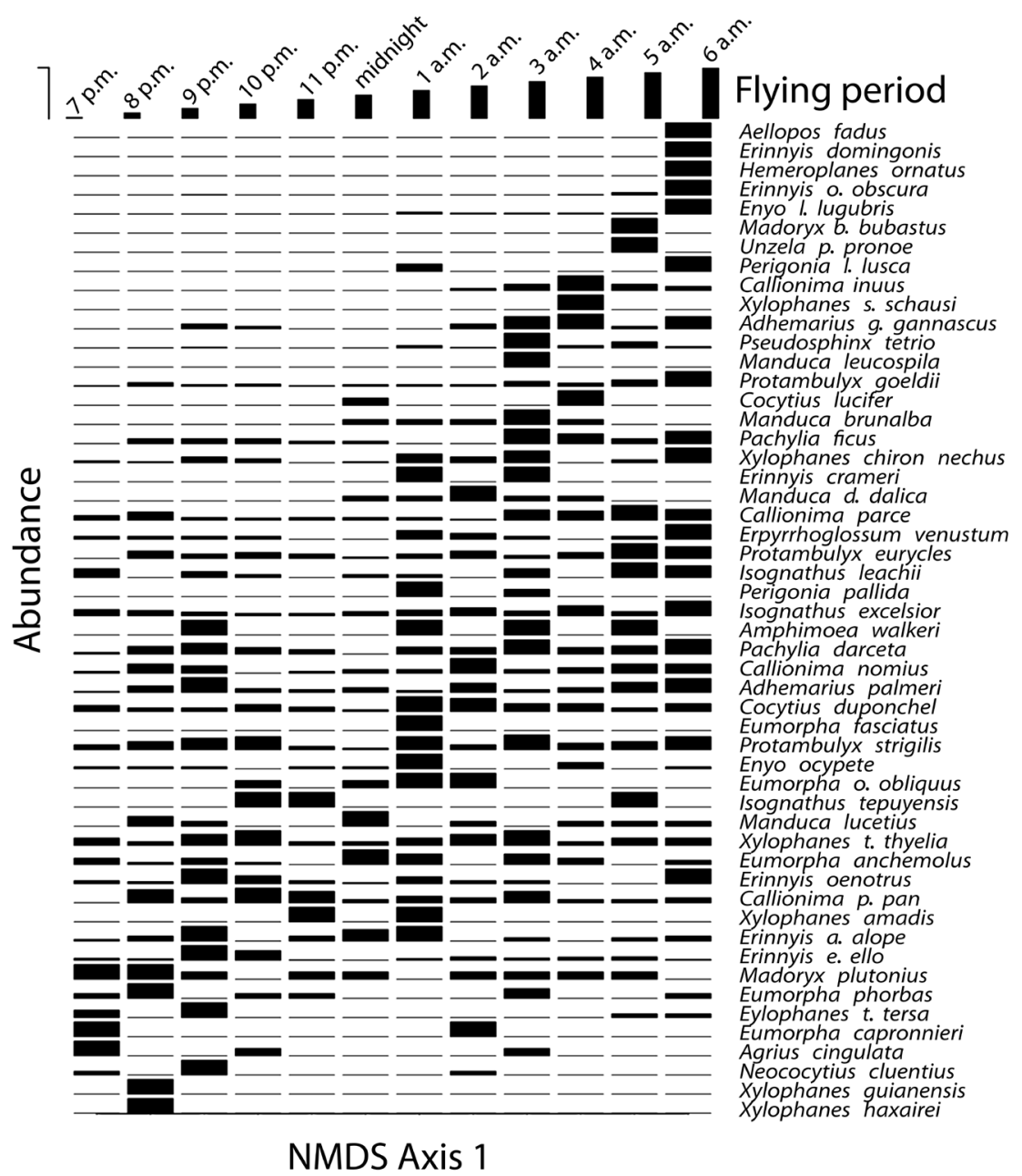

Figure 4. Hawkmoth species turnover across the 12 hourly intervals. 


\section{DISCUSSION}

The collection of a relatively larger quantity of sphingids from rainforest canopy, in relation to sampling at ground level, is an indication that the species fly over the treetops, possibly for dispersal, foraging, and seeking the opposite sex for mating (also observed in Hedylidae by Lourido et al. 2008). The environment of the canopy allows for the attraction of large numbers of species because light can propagate over a long distance without the common obstacles encountered in pathways and clearings at ground level.

We sampled approximately $40 \%$ of the recorded species of hawkmoths from the Amazonia (128 spp.) and 26\% of those registered from Brazil (197 spp.). Not surprisingly, the species accumulation curve did not stabilize. Thus, we expect that more species should be recorded as sampling time increases, even though the addition of species decreased continuously from the eighth month on. For this reason, we encourage other studies to consider a similar sampling effort in order to maximize the representativeness of species diversity in hawkmoth surveys. Most of the recorded species belong to Macroglossinae, a subfamily that often has high species richness and abundance in both Amazonian (Motta et al. 1991; Motta et al. 1998; Motta and Andreazze 2001; 2002; Motta and Xavier Filho 2005) and non-Amazonian landscapes in Brazil (Laroca and Mielke 1975; Ferreira et al. 1986; Laroca et al. 1989; Marinoni et al. 1999; Darrault and Schlindwein 2002; Gusmão and Creão-Duarte 2004; Duarte Jr. and Schlindwein 2005a; b; Duarte et al. 2008, Vieira et al. 2015). In particular, the tribe Dilophonotini, the most species-rich tribe in our survey, comprises about $58 \%$ of the hawkmoth species richness registered from the Amazon (Camargo 2016a). In addition, our results are concordant with previous diversity patterns regarding genera, as Xylophanes and Erinnyis are acknowledged as rich and abundant genera in the Amazon (Laroca and Mielke 1975; Ferreira et al. 1986; Laroca et al. 1989; Laroca et al. 1989; Motta et al. 1991; Motta et al. 1998; Motta and Andreazze 2001; 2002; Motta and Xavier Filho 2005).

We observed that few species tended to be associated with a particular season. For instance, Pseudosphinx tetrio was mostly recorded in the dry season. However, Isognathus excelsior and Callionima parce did not differ in abundance between seasons. Furthermore, despite being more abundant in the rainy season in our study, Erinnyis ello ello was much more abundant in the dry season from nearby Amazon locations (Motta et al. 1998). This may indicate that this species is able to adapt to both environmental conditions or that differences in the methodological procedure could have rendered divergent patterns.

The high amount of species with low relative abundance (and fewer highly abundant species) is an ordinary pattern of insect communities in tropical forests (e.g., Tarli et al. 2014; Graça et al. 2015). For hawkmoths in particular, this may be due to (1) limiting resources, which should intensify competitive exclusion and benefit few highly competitive species, (2) between-species heterogeneity in sensibility to light, so that less sensitive species should be collected in smaller quantities or (3) limitation in light propagation, so that we were not able to reach farther areas that might have increased the abundance of these rare species (Narvaéz and Soriano 1996).

The most abundant species were constant throughout the night, but with the highest peak at different time intervals. Such differences may be related to competition for resources or defense against predation (Camargo et al. 2016a; Camargo et al. 2016b). The low capture during dusk (6 to 7 p.m.) may have a methodological cause, since in this period the sun is not completely set and the sunlight influence could have rendered our light trap less attractive (Narvaéz and Soriano 1996), or it may reflect a real activity pattern in the community, and there are less hawkmoths flying in this period than late at night.

Males were predominant in the light traps and this may be associated with physiological peculiarities between the sexes. Males are more susceptible to light because they often rely on light patterns during female seeking (Janzen 1983), while the females tend to be more stationary to release pheromones (Motta 2009). In addition, females tend to be heavier and have less flight power than males (Johnson 1963; Berwaerts et al. 2002) and most females mate soon after emergence and tend to spend time searching for host plants, which lowers their representativeness in light traps (Silveira-Neto et al. 1976).

\section{CONCLUSIONS}

Our study showed that, even though Sphingidae is a relatively well-studied group of moths, there is still much novel information to be recorded, especially from the canopy of tropical forests. We also revealed how the community structure responded to small (night period) and large (year) temporal scales. If a comprehensive inventory is the aim, we recomend sampling effort of at least eight months and throughout the entire night to properly describe the canopy Sphingidae diversity. We hope that this survey encourages the use of light traps to collect hawkmoths that inhabit the canopy of other Amazonian locations and tropical forests in general, which will eventually lead to (1) an increase in the knowledge of local and overall hawkmoth diversity, (2) the potential discovery of new species, and (3) and the increment in data bases that support conservationist policies.

\section{ACKNOWLEDGMENTS}

To Drs. Niro Higuchi and Joaquim dos Santos, for permitting the use of the Experimental Station of Tropical Silviculture of INPA. To Alexandre da Silva Filho (in memoriam), Alexandre U. Rodrigues, Fábio P.S. Godoi, Francisco F. Xavier Filho, José M. Ribeiro, Joseleide T. Câmara and Simone F. Trovisco, for their help in fieldwork. To Conselho Nacional de Desenvolvimento Científico e Tecnológico (CNPq), for financial support through 
proc. 472978/2003-9 (ZO). J.A. Rafael is research productivity fellow from CNPq. G.M. Lourido and M.B. Graça received a postdoctoral and a doctoral fellowship, respectively, from the Fundaçáo de Amparo à Pesquisa do Estado do Amazonas (FAPEAM).

\section{REFERENCES}

Barbosa, P.H.D.; Costa, A.C.L. da; Cunha, A.C. da; Silva Junior, J. A. 2015. Variabilidade de elementos meteorológicos e de conforto térmico em diferentes ambientes na Amazônia brasileira. Revista Brasileira de Climatologia, 17: 98-118.

Berwaerts, K.; Van Dyck, H.; Aerts, P. 2002. Does flight morphology relates to flight performance? An experimental test with the butterfly Pararge aegeria. Functional Ecology, 16: 484-491.

Camargo, J.A. de; Camargo, N.F. de; Corrêa, D.C.V.; Camargo, W.R.F. de; Vieira, E.K.M.; Marini-Filho, O.; Amorim, F.W. 2016a. Diversity patterns and chronobiology of hawkmoths (Lepidoptera, Sphingidae) in the Brazilian Amazon rainforest. Journal of Insect Conservation, 20: 629-641.

Camargo, N. F. de; Camargo, W.R.F. de; Corrêa, D.C.V; Camargo, A.J.A. de; Vieira, E.M. 2016b. Adult feeding moths (Sphingidae) differ from non-adult feeding ones (Saturniidae) in activity-timing overlap and temporal niche width. Oecologia, 180: 313-324.

Carcasson, R.H.; Heppner, J.B. 1996. Sphingoidea, Sphingidae. In: Heppner, J. B. (Ed.). Atlas of Neotropical Lepidoptera Check List. Part. 4B. Drepanoidea, Bombycoidea, Sphingoidea. Association for Tropical Lepidoptera, Scientific Publishers, Gainesville, p. 50-62.

Colwell, R.K. 2013. EstimateS: Statistical estimation of species richness and shared species from samples (http://purl.oclc.org/ estimates). Accessed on 09/12/2017.

D'Abrera, B. 1986. Sphingidae Mundi. Hawkmoths of the World. Classey E.W., Oxon, 266 p.

Dantas, Y.K.L.; Rafael, J.A.; Motta, C.S.; Agudelo, A.A.; Xavier Filho, F.F. 2008. Registros de Mantodea (Insecta) coletados à luz no dossel da floresta, na torre do km 14 do núcleo ZF-2, Manaus, Brasil. Acta Amazonica, 38: 317-320.

Darrault, R.O.; Schlindwein, C. 2002. Esfingídeos (Lepidoptera, Sphingidae) no tabuleiro paraibano, Nordeste do Brasil: abundância, riqueza e relaçấo com plantas esfingófilas. Revista Brasileira de Zoologia, 19: 429-443.

Duarte Jr., J.A.; Schlindwein, C. 2005a. Riqueza, abundância e sazonalidade de Sphingidae (Lepidoptera) num fragmento de Mata Atlântica de Pernambuco, Brasil. Revista Brasileira de Zoologia, 22: 662-664.

Duarte Jr, J.A.; Schlindwein, C. 2005b. The highly seasonal hawkmoth fauna (Lepidoptera: Sphingidae) of the caatinga of northeast Brazil: a case study in the state of Rio Grande do Norte. Journal of the Lepidopterists' Society, 59: 212-218.

Duarte, M.; Carlin, L.F.; Marconato, G. 2008. Light-attracted hawkmoths (Lepidoptera: Sphingidae) of Boracéia municipality of Salesópolis, State of São Paulo, Brazil. Checklist, 4: 123-136.

Duarte, M; Camargo, A.J.A. de; Mielke, C.G.C.;Mielke, O.H.H. 2017. Sphingidae. In: Catálogo Taxonômico da Fauna do Brasil
(http://fauna.jbrj.gov.br/fauna/listaBrasil/ConsultaPublicaUC/ ConsultaPublicaUC.do). Accessed on 24/05/2017.

Ferreira, P.S.F.; Martins, D.S.; Hübner, N. 1986. Levantamento, flutuação e análise entomofaunística em mata remanescente da Zona da Mata, Viçosa, Minas Gerais. I. Sphingidae: Lepidoptera. Revista Ceres, 33: 516-527.

Graça, M.B.; Morais, J.W.; Franklin, E.; Pequeno, P.A.C.L.; Souza, J.L.P.; Bueno, A.S. 2015. Combining taxonomic and functional approaches to unravel the spatial distribution of an Amazonian butterfly community, Enviromental Entomology, 45: 301-309.

Gusmão, M.B.; Creão-Duarte, A.J. 2004. Diversidade e análise faunística de Sphingidae (Lepidoptera) em área de brejo e caatinga no Estado da Paraíba, Brasil. Revista Brasileira de Zoologia, 21: 491-498.

Higuchi, N.; Pereira, H.S.; Santos, J.; Lima, A.J.N.; Higuchi, F.G.; Higuchi, M.I.G.; Ayres I.G.S.S. 2009. Governos locais amazônicos e as questôes climáticas globais. Edição dos autores, Manaus. 103p.

Janzen, D.H. 1983. Insects. In: Janzen, D.H. (Ed.). Costa Rican Natural History. The University of Chicago Press, Chicago and London, p. 619-779.

Johnson, C.G. 1963. Physiological factors in insect migration by flight. Nature, 198: 423-427.

Kitching, I.J.; Cadiou, J.M. 2000. Hawkmoths of the World: an annotated and ilustrated revisionary checklist (Lepidoptera: Sphingidae). Cornell University Press, Ithaca, 227p.

Krolow, T.K.; Henriques, A.L.; Rafael, J.A. 2010. Tabanidae (Diptera) no dossel da Floresta amazônica atraídos por luz e descrição de machos de três espécies. Acta Amazonica, 40: 605-612.

Laroca, S.; Becker, V.O.; Zanella, F.C.V. 1989. Diversidade, abundância relativa e fenologia em Sphingidae (Lepidoptera) na Serra do Mar (Quatro Barras, PR), Sul do Brasil. Acta Biológica Paranaense, 18: 13-53.

Laroca, S.; Mielke, O.H.H. 1975. Ensaios sobre Ecologia de comunidades em Sphingidae da Serra do Mar, Paraná, Brasil (Lepidoptera). Revista Brasileira de Biologia, 35: 1-9.

Lourido, G.M.; Motta, C.S.; Rafael, J.A.; Morais, J.W.; Xavier Filho, F.F. 2008. Hedylidae (Lepidoptera: Hedyloidea) coletados à luz a 40 metros de altura no dossel da floresta da Estaçáo de Silvicultura Tropical em Manaus, Amazonas, Brasil. Acta Amazonica, 38: 329-332.

Machado, R.J.P. 2007. Taxonomia e sazonalidade das espécies de Mantispidae (Insecta: Neuroptera) da Amazônia brasileira. Dissertação de Mestrado, Instituto Nacional de Pesquisas da Amazônia/Universidade Federal do Amazonas, Manaus, Amazonas. 140p.

Machado, R.J.P.; Rafael, J.A. 2007. A new Mantispidae (Insecta: Neuroptera) from Central Amazonia, Brazil. Zootaxa, 1530: 37-40.

Marinoni, R.C.; Dutra, R.R.; Mielke, O.H.H. 1999. Levantamento da fauna entomológica no estado do Paraná. IV. Sphingidae (Lepidoptera). Diversidade alfa e estrutura de comunidade. Revista Brasileira de Zoologia, 16: 223-240.

Martins, U.R.; Galileo, M.H.M.; Santos-Silva, A.; Rafael, J.A. 2006. Cerambycidae (Coleoptera) coletados à luz a 45 metros de altura, no dossel da floresta amazônica, e a descrição de quatro espécies novas. Acta Amazonica, 36: 265-272. 
Minchin, P.R. 1987. An evaluation of the relative robustness of techniques for ecological ordination. Vegetatio, 69: 89-107.

Motta, C.S. 1993. Mariposas Esfingídeas (Lepidoptera, Sphingidae) da Amazônia Brasileira e o Meio Ambiente.In:Ferreira, E.J.G.; Santos, G.M.; Leão, E.L.M.; Oliveira. L.A. (Eds.) Bases Científicas para Estratégias de Preservação e Desenvolvimento da Amazônia - Fatos e Perspectivas.vol. 2. Editora INPA, Manaus, p. 141-146.

Motta, C.S. 2009. Sphingidae. In: Fonseca, C.R.V.; Magalhães, C.; Rafael, J.A.; Franklin, E. (Orgs.). A fauna de artrópodes da Reserva Florestal Ducke: estado atual do conhecimento taxonômico e biológico. Editora INPA, Manaus, p. 153-157

Motta, C.S.; Aguilera-Peralta, F.J.; Andreazze, R. 1998. Aspectos da Esfingofauna (Lepidoptera, Sphingidae), em área de terra-firme, no estado do Amazonas, Brasil. Acta Amazonica, 28: 75-92.

Motta, C.S.; Andreazze, R. 2001. Esfingofauna (Lepidoptera: Sphingidae) do Parque Nacional do Jaú e arredores, Amazonas, Brasil. Acta Amazonica, 31: 643-654.

Motta, C.S.; Andreazze, R. 2002. Sphingidae (Lepidoptera) de Querari, São Gabriel da Cachoeira, Amazonas, Brasil. Entomologia y Vectores, 9: 329-337.

Motta, C.S.; Ferreira, R.L.M.; Aguiar, N.O. 1991. Sobre a esfingofauna da Ilha de Maracá e da Serra da Pacaraima, Roraima (Lepidoptera, Sphingidae). Acta Amazonica, 21: 319-324.

Motta, C.S.; Xavier Filho, F.F. 2005. Esfingídeos (Lepidoptera, Sphingidae) do município de Beruri, Amazonas, Brasil. Acta Amazonica, 35: 457-462.
Narváez, Z.; Soriano, P.J. 1996. Composicion y estructura de la comunidad de Sphingidae (Insecta: Lepidoptera) de una selva nublada andina. Ecotropicos, 9: 9-20.

Oksanen, J.; Blanchet, F.G.; Friendly, M.; Kindt, R.; Legendre, P.; McGlinn, D.; et al. 2016. Vegan: Community ecology package (http://cran.r-project.org/web/packages/vegan). Accessed on $09 / 12 / 2017$.

R Core Team. 2017. R: A language and environment for statistical computing. Vienna, Austria (http://www.R-project.org/). Accessed on 09/12/2017.

Silveira Neto, S.; Nakano, O.; Décio, B.; Villa Nova, N.A. 1976. Manual de ecologia dos insetos. Agronômica Ceres, São Paulo. 419p.

Tarli, V.D.; Pequeno, P.A.C.L.; Franklin, E.; Morais, J.W.; Souza, J.L.P.; Oliveira, A.H.C.; Guilherme, D.R. 2014. Multiple environmental controls on cockroach assemblage structure in a tropical rain forest. Biotropica, 46: 598-607.

Vieira, K.C.R.; Moraes, S.S.; Chiquetto-Machado, P.I.; Duarte, M. 2015. Crepuscular and nocturnal hawkmoths (Lepidoptera: Sphingidae) from a fragment of Atlantic rainforest in the state of São Paulo, southeastern Brazil. Florida Entomologist, 98: 342-348.

RECEIVED: 29/12/2017

ACCEPTED: 04/02/2018

ASSOCIATE EDITOR: Fabrício Baccaro 